\title{
MENINGKATKAN KETERBUKAAN DIRI SISWA MELALUI LAYANAN BIMBINGAN KELOMPOK PADA SISWA KELAS $X$ SMA NEGERI 4 KOTA LUBUKLINGGAU
}

\author{
Tara Luciana, Hadiwinarto, Syahriman \\ Prodi Bimbingan dan Konseling Fakultas Keguruan dan Ilmu Pendidikan \\ Universitas Bengkulu \\ taraluciana03@gmail.com, hadiwin@unib.ac.id, syahriman@unib.ac.id
}

\begin{abstract}
ABSTRAK
Penelitian ini bertujuan untuk mendeskripsikan peningkatan keterbukaan diri siswa melalui layanan bimbingan kelompok pada siswa kelas X SMA Negeri 4 Kota Lubuklinggau. Metode yang digunakan dalam penelitian ini adalah metode eksperimen dengan desain penelitian one group pre-test and post-test design. Subjek dalam penelitian ini adalah 14 orang siswa yang memiliki keterbukaan diri yang rendah dan sangat rendah. Teknik pengumpulan data menggunakan angket (kuesioner). Sedangkan teknik analisis data menggunakan uji $t$. Hasil penelitian ini menunjukkan keterbukaan diri siswa meningkat setelah diberikan layanan bimbingan kelompok. Hal ini terlihat dari mean pre-test $=60$ dan mean post-test $=90$ dengan nilai uji beda $t$ yaitu $t_{\text {hitung }}=41,168>\mathrm{t}_{\text {tabel }}=2,160$ dan $\mathrm{p}=0,000(\mathrm{p}<0,05)$. Artinya ada peningkatan keterbukaan diri siswa secara signifikan setelah diberikan layanan bimbingan kelompok.
\end{abstract}

Kata kunci:keterbukaan diri, layanan bimbingan kelompok

\section{IMPROVING STUDENT'S SELF-DISCLOSURE THROUGH THE GROUP GUIDANCE SERVICESON STUDENTSOFGRADEX SMA NEGERI 4 KOTA LUBUKLINGGAU}

\begin{abstract}
This study aims to describe the increased self-disclosure of students through group guidance services on students of grade X SMA Negeri 4 Kota Lubuklinggau. The method used in this research is experimental method with one group pre-test and post-test design.Subjects in this study were 14 students who have low self-disclosure and very low. The data collection was done through questionnaire. While the data was analysed by $t$ test. The results of this study showed that students' self-disclosure increased after being given group guidance services. This can be seen from themean pre-test $=60$ andmean post-test $=90$ with the value of $t_{\text {test }}=$ $41,168>t_{\text {table }}=2,160$ and $p=0,000(p<0,05)$. This means that there is an increase in students' self-disclosure significantly after being given group guidance services.
\end{abstract}

Keywords:self-disclosure, group guidance services 


\section{Pendahuluan}

Pendidikan adalah hal yang amat penting di dalam kehidupan manusia. Melalui pendidikan, individu mampu untuk mengoptimalkan serta mengembangkan kemampuan yang dimilikinya, melaksanakan tugas-tugas perkembangannya, dan mampu untuk melaksanakan tanggung jawabnya. Hal tersebut selaras dengan fungsi dari pendidikan nasional yang tertera pada Undang-Undang Republik Indonesia No. 20 tahun 2003 tentang Sistem Pendidikan Nasional (dalam Syahrizal \& Sugiarto, 2013: 17) yang berbunyi "Pendidikan nasional berfungsi mengembangkan kemampuan dan membentuk watak serta peradaban bangsa yang bermartabat dalam rangka mencerdaskan kehidupan bangsa".

Ada beberapa jenis pendidikan yang dapat diterima oleh individu, salah satunya adalah pendidikan formal. Menurut Undang-Undang Republik Indonesia No 20 tahun 2003 dijelaskan bahwa pendidikan formal adalah pendidikan yang diberikan secara berjenjang di satuan pendidikan seperti sekolah. Sekolah selalu identik dengan belajar, namun di dalamnya lagi terdapat hal yang tidak dapat dipisahkan yaitu sosialisasi antar individu. Kemampuan bersosialisasi individu dapat dilihat berdasarkan kemampuannya untuk dapat terbuka.

Menurut Johnson (dalam Mulyati, et al., 2000: 22) membuka diri adalah mengemukakan bagaimana reaksi terhadap situasi yang dialami saat ini dan memberikan informasi yang relevan mengenai masa lalu sebagai usaha untuk memahami mengapa pada saat ini muncul reaksi tertentu. Individu mampu membagi apa yang dirasakannya terhadap suatu hal. Sehingga dapat terjalin komunikasi yang baik sebagai akibat dari membuka diri.

Sehubungan dengan pengertian membuka diri, pada saat ini masih banyaknya siswa yang tidak terbuka akan dirinya serta tidak mampu untuk menyampaikan pendapatnya ataupun informasi tentang dirinya. Selain itu, siswa akan menunjukkan sikap terbuka hanya pada orang-orang tertentu seperti pada orang-orang dalam suatu kelompok kecil (klik) tertentu yang juga ia ikuti. Dalam satu kelas, hampir seluruh siswa menggabungkan diri dalam kelompok tertentu. Padahal untuk menjalin komunikasi yang baik, individu satu dan yang lainnya harus mampu untuk terbuka.

Komunikasi efektif amat membantu individu dalam membuka dirinya. Oleh karena itu, dalam suatu hubungan interpersonal diperlukan kemampuan berkomunikasi yang efektif (Mulyati, et al., 2000: 32). Selain itu, menurut Mulyati, et al (2000: 32) komunikasi interpersonal diartikan sebagai pesan yang disampaikan sumber kepada seseorang atau 
beberapa orang penerima. Sehingga setiap orang menerima informasi, memberi informasi, menginterpretasikannya serta menyimpulkannya.

Layanan bimbingan kelompok adalah proses pemberian bantuan yang memanfaatkan dinamika kelompok dalam mengentaskan permasalahan yang dibahas dalam kegiatan. Prayitno (1995: 178) menyatakan bahwa bimbingan kelompok adalah suatu kegiatan yang dilakukan oleh sekelompok orang dengan memanfaatkan dinamika kelompok. Selama kegiatan bimbingan kelompok berlangsung, masing-masing anggota kelompok harus berperan aktif serta mampu untuk menyampaikan informasi tentang dirinya, menyampaikan pendapatnya tentang suatu hal. Saling mengutarakan pendapat dapat menghidupkan kegiatan dengan memanfaatkan dinamika kelompok.

Layanan bimbingan kelompok amat penting dilaksanakan di sekolah. Hal tersebut dikarenakan pada kegiatannya selain anggota kelompok dituntut untuk mampu menyampaikan informasi pribadi dan pendapat, tetapi juga harus mampu untuk mengembangkan kemampuannya dalam memimpin, serta mengutarakan pendapatnya, menyampaikan informasi tentang dirinya. Selain itu, anggota kelompok juga dituntut untuk mampu berbaur atau melibatkan diri dengan anggota kelompok yang lain.

Masalah yang dibahas dalam kegiatan bimbingan kelompok adalah materi-materi yang bersifat umum. Menurut Sukardi (2008: 65) menyatakan bahwa materi layanan bimbingan kelompok yaitu pengembangan kemampuan berkomunikasi, menerima/menyampaikan pendapat, bertingkah laku dan hubungan sosial, baik di rumah, sekolah, maupun di masyarakat, teman sebaya di sekolah dan luar sekolah dan kondisi/peraturan sekolah.

Sejalan dengan pengertian dari bimbingan kelompok, dapat disimpulkan bahwa kegiatan layanan bimbingan kelompok sangat cocok dalam mengentaskan masalah siswa mengenai keterbukaan diri. Hal itu dapat dilihat berdasarkan pada kegiatan bimbingan kelompok memanfaatkan dinamika kelompok. Oleh karena itu, siswa dapat bersikap terbuka dengan cara siswa mengutarakan pendapatnya, idenya, melibatkan dirinya, serta mampu mengutarakan perasaan serta pikirannya.

\section{Metode Penelitian}

Desain penelitian yang digunakan adalah One-Group Pretest-Posttest Design. Pada penelitian ini akan dilakukan 2 (dua) kali pengukuran yaitu sebelum diberikan perlakuan (pretest) dan setelah diberikan perlakuan (posttest) yang diberikan kepada subjek penelitian. 
Populasi dari penelitian ini adalah seluruh siswa kelas X MIPA 4 SMA Negeri 4 Kota Lubuklinggau yang berjumlah 35 orang yang dipilih sebanyak 14 orang untuk menjadi subjek penellitian. Teknik pengambilan subjek penelitian adalah purposive sampling.Zuriah (2009: 141) menyatakan teknik pengambilan subjek ini berorientasi kepada pemilihan sampel di mana populasi dan tujuan yang spesifik dari penelitian, diketahui oleh peneliti sejak awal. Subjek penelitian dipilih berdasarkan skor angket pre-test rendah dan sangat rendah.

Teknik pengumpulan data yang digunakanberupa angket (kuesioner). Kuesioner (angket) merupakan teknik pengumpulan data yang dilakukan dengan cara memberi seperangkat pertanyaan atau pernyataan tertulis kepada responden untuk dijawabnya (Sugiyono, 2012:199). Dalam penelitian ini, angket yang digunakan untuk mengetahui keterbukaan diri siswadengan model skalaLikert.

Ujivaliditasinstrumenpenelitianmenggunakanrumuskorelasiproduct moment.Sebelum melakukan bimbingan kelompok, instrumen penelitian terlebih dahulu diuji cobakan kepada siswa untuk dilakukan uji validitas yang diolah dengan aplikasi SPSS (Software Statistical Packages for Social Science). Berdasarkan uji validitas tersebut, tersisa sebanyak 19 item soal yang dinyatakan valid dengan catatan r (Corrected Item-Total Correlation) lebih dari 0,334. Sedangkan nilai $r$ tertinggi adalah 0,581 dan nilai $r$ terendah adalah $-0,77$.

Nilai uji reliabilitas dapat dikatakan kuat jika Cronbach's Alpha antara 0,60 - 0,799. Nilai Cronbach's Alpha pada instrumen penelitian adalah 0,794 sehingga instrumen dapat dikatakan reliabel atau dapat dipercaya sebagai instrumen penelitian.

\section{Hasil dan Pembahasan}

Berdasarkan hasil analisis, diperoleh rentang kelas interval dan ketgorinya berdasarkan skor ideal. Skor ideal disusun berdasarkan skor total skor tertinggi dan total skor terendah berdasarkan jumlah butir instrumen. Sehingga dapat ditentukan kelas interval dan kategorinya yang disajikan pada tabel di bawah ini:

Tabel 1

Rentang Kelas Interval dan Kategori

\begin{tabular}{cc}
\hline Interval Skor & Kategori \\
\hline$\geq 79$ & Sangat tinggi \\
\hline $64-78$ & Tinggi \\
\hline $49-63$ & Sedang \\
\hline $34-48$ & Rendah \\
\hline $19-33$ & Sangat rendah \\
\hline
\end{tabular}


Pada Tabel 2 diperoleh kategori hasil pre-test siswa yang menjadi sampel penelitian yang memiliki keterbukaan diri sedang. Seluruh siswa yang menjadi sampel penelitian yaitu 14 orang memiliki keterbukaan diri sedang.

Tabel 2

Kategori Hasil Pre-Test

\begin{tabular}{ccc}
\hline Kategori & Frequency & Percent \\
\hline Sangat Tinggi & - & - \\
\hline Tinggi & - & - \\
\hline Sedang & 14 & $100 \%$ \\
\hline Rendah & - & - \\
\hline Sangat Rendah & - & - \\
\hline Jumlah & $\mathbf{1 4}$ & $\mathbf{1 0 0 \%}$ \\
\hline
\end{tabular}

Pada Tabel 3 yang merupakan kategori post-test, diperoleh hasil post-test siswa yang menjadi sampel penelitian. Sebanyak 14 orang siswa yang menjadi sampel penelitian memiliki keterbukaan diri sangat tinggi.Keterbukaan diri siswa meningkat setelah diberikan perlakuan berupa layanan bimbingan kelompok.

Tabel 3

Kategori Hasil Post-Test

\begin{tabular}{ccc}
\hline Kategori & Frequency & Percent \\
\hline Sangat Tinggi & 14 & $100 \%$ \\
\hline Tinggi & - & - \\
\hline Sedang & - & - \\
\hline Rendah & - & - \\
\hline Sangat Rendah & - & - \\
\hline Jumlah & $\mathbf{1 4}$ & $\mathbf{1 0 0 \%}$ \\
\hline
\end{tabular}

Hipotetsis pada penelitian ini untuk menguji pengaruh layanan bimbingan kelompok dalam meningkatkan sikap keterbukaan diri siswa kelas X SMA Negeri 4 Kota Lubuklinggau. Untuk menguji hipotesis tersebut menggunakan rumus uji-t dengan menggunakan aplikasi SPSS (Software Statistical Packages for Social Science)

Tabel 4

Uji Hipotesis

\begin{tabular}{cr}
\hline & \multicolumn{1}{c}{ Pretest - Posttest } \\
\hline $\mathbf{t}$ & $-41,168$ \\
\hline Sig. (2-tailed) & .000
\end{tabular}

Berikut adalah ketentuan dalam menguji hipotesis penelitian dengan rumus uji Wilcoxon Match Pairs Test yaitu 1) $\mathrm{H}_{0}$ di tolak dan $\mathrm{Ha}$ apabila $\mathrm{t}_{\text {hitung }}>\mathrm{t}_{\text {tabel}}$, dan 2) $\mathrm{H}_{0}$ 
diterima dan Ha ditolak apabila $t_{\text {hitung }}<\mathrm{t}_{\text {tabel }}$. Berdasarkan hasil perhitungan uji $t$, diperoleh

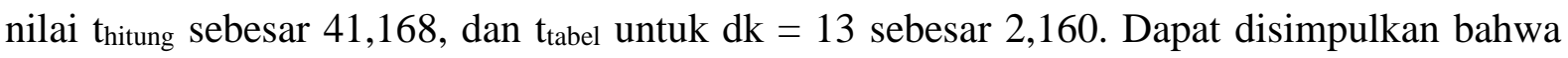
$t_{\text {hitung }}>\mathrm{t}_{\text {tabel}}$, yang artinya bahwa $\mathrm{H}_{0}$ ditolak dan $\mathrm{Ha}$ diterima. Sehingga ada peningkatan keterbukaan diri siswa melalui layanan bimbingan kelompok pada siswa kelas X SMA Negeri 4 Kota Lubuklinggau. Tanda negatif pada nilai uji t dapat diidentifikasikan terjadi peningkatan keterbukaan diri secara signifikan melalui layanan bimbingan kelompok.

Sebelum diberikan layanan bimbingan kelompok, keterbukaan diri siswa dapat dilihat dari skor pre-test. Berdasarkan skor pre-test, keterbukaan diri siswa sedang. Sebanyak 14 orang siswa memiliki keterbukaan diri yang sedang. Hal ini disebabkan oleh banyaknya anggota kelas yang membentuk kelompok-kelompok kecil di dalam kelas. Selain itu, kurangnya keterbukaan antara satu sama lainnya antar anggota kelas, serta hanya kepada orang-orang tertentu saja mereka akan terbuka.

Proses peningkatan keterbukaan diri siswa ditunjukkan pada proses pelaksanaan kegiatan bimbingan kelompok. Perlakuan (treatment) yang dilakukan sebanyak 4 (empat) kali pertemuan. Setelah kegiatan bimbingan kelompok sebanyak 4 (empat) kali pertemuan, pemimpin kelompok mengadakan post-test kepada anggota kelompok.

Berdasarkan skor post-test, keterbukaan diri siswa menjadi kategori sangat tinggi, yang sebelumnya hanya pada kategori sedang. Seluruh sampel penelitian yaitu sebanyak 14 orang memiliki keterbukaan diri sangat tinggi. Sehingga terjadi peningkatan antara sebelum diberikan layanan bimbingan kelompok dan setelah diberikan layanan bimbingan kelompok.

Perubahan skor tersebut terjadi dikarenakan pada pelaksanaan layanan bimbingan kelompok dibahas secara detail mengenai keterbukaan diri siswa yang juga merupakan kisikisi angket yang digunakan. Selain itu, kelompok yang digunakan adalah kelompok tugas sehingga sebelum pelaksanaannya siswa terlebih dahulu mencari materi yang akan dibahas selanjutnya.

Berdasarkan uji hipotesis yang dilakukan, nilai $t_{\text {hitung }}=41,168>t_{\text {tabel }}=2,160$ yang artinya bahwa $\mathrm{H} 0$ ditolak dan Ha diterima. Sehingga ada peningkatan keterbukaan diri siswa melalui layanan bimbingan kelompok pada siswa kelas X SMA Negeri 4 Kota Lubuklinggau. Selain itu, tanda negatif yang terdapat pada nilai thitung berarti terjadi peningkatan yang signifikan antara sebelum dan sesudah pemberian layanan bimbingan kelompok.

Berdasarkan pertemuan pertama sampai dengan pertemuan ke empat, dapat dianalisis bahwa anggota kegiatan bimbingan kelompok sudah memahami topik yang dibahas pada 
setiap pertemuan. Anggota bimbingan kelompok menunjukkan perubahana sikap pada setiap proses kegiatan bimbingan kelompok dan sudah mampu menerapkan hasil bimbingan sebelumnya ke bimbingan kelompok selanjutnya.

Hal ini sejalan dengan teori yang pernah diteliliti oleh Hanifa (2013: 1) menyatakan bahwa nilai $t_{\text {hitung }}=55,0>\mathrm{t}_{\text {tabel }}=8,0$ menunjukkan seluruh indikator signifikan dengan taraf siginifikan 5\%. Hasil penelitian dari pre test dan post test menunjukkan bahwa secara keseluruhan masalah rendahnya keterbukaan diri dalam komunikasi antar teman sebaya yang dialami siswa tersebut menjadi lebih tinggi setelah mendapatkan treatment jika dibandingkan dengan sebelum mendapatkan treatment.

Sejalan dengan hal itu, penelitian yang dilakukan oleh Setyaningsih (2017: 8) menyatakan bahwa jika keterbukaan diri siswa tinggi, siswa dapat lebih menunjukkan kemampuan dalam memecahkan masalah sendiri, memiliki kemampuan komunikasi yang cukup dengan orang-orang disekitarnya, dan tidak membatasi dari ras, jenis kelamin, warna kulit, dan siswa bebas mengemukakan pendapatya, dan bisa saling memahami satu sama lain.

Berdasarkan hasil penelitian yang dilakukan, kesimpulan yang diperoleh berdasarkan pengertian serta jenis bimbingan kelompok. Menurut Asmani (2010: 115), layanan bimbingan kelompok yaitu layanan bimbingan dan konseling yang memungkinkan peserta didik (klien), secara bersama-sama, melalui dinamika kelompok, memperoleh berbagai bahan dari narasumber tertentu (terutama dari guru pembimbing), membahas secara bersama-sama pokok bahasan (topik) tertentu yang berguna untuk menunjang untuk pemahaman dan kehidupannya mereka sehari-hari, dan atau untuk pengembangan kemampuan sosial, baik sebagai individu maupun sebagai pelajar. Menurut Prayitno (1995: 25), pada kelompok tugas, perhatian diarahkan kepada satu titik pusat, yaitu menyelsaikan tugas.

Berdasarkan penjabaran tersebut, perhatian anggota kelompok dipusatkan pada satu titik pusat yaitu untuk meningkatkan keterbukaan diri anggota kelompok. Di dalam pelaksanaannya, topik bahasan yang telah ditentukan sebelumnya yang berkaitan dengan meningkatkan keterbukaan diri siswa, dibahas secara bersama-sama dengan memanfaatkan dinamika kelompok.

Menurut Prayitno (2004: 2), tujuan umum bimbingan kelompok adalah berkembangnya kemampuan sosialisasi siswa, khususnya kemampuan komunikasi peserta layanan.Tujuan bimbingan kelompok yang dijabarkan yaitu mengembangkan kemampuan anggota kelompok dalam bersosialisasi khususnya yaitu kemampuan komunikasi. Topik yang dibahas adalah 
topik-topik yang bersifat umum. Menurut Sukardi (2008: 65), salah satu materi layanan bimbingan kelompok adalah pengembangan kemampuan berkomunikasi, menerima/menyampaikan pendapat, bertingkah laku dan hubungan sosial, baik di rumah, sekolah, maupun di masyarakat, teman sebaya di sekolah dan luar sekolah dan kondisi/peraturan sekolah.

Antara tujuan dan materi yang dibahas bersifat umum sehingga dirasakan menjadi suatu kepentingan bersama untuk meningkatkan ataupun mengembangkan kemampuan bersosialisasi angota kelompok. Oleh karena itu, kedudukan setiap anggota kelompok adalah saling berhubungan atau saling berinteraksi antara satu dan lainnya. Sehingga setiap anggota kelompok haus mampu terbuka dalam menyampaikan informasi pribadi, pendapat, saran, atau tanggapan atas suatu hal agar tujuan bimbingan kelompok dapat tercapai.

Sesuai dengan judul skripsi ini yaitu meningkatakan keterbukaan diri siswa melalui layanan bimbingan kelompok, siswa mampu meningkatkan keterbukaan diri khususnya pada siswa kelas X MIPA 4 SMA Negeri 4 Kota Lubuklinggau. Sesuai dengan uraian tersebut, maka dapat disimpulkan bahwa bimbingan kelompok dapat meningkatkan keterbukaan diri siswa, sehingga dapat diketahui bahwa harapan dari penelitian ini tercapai.

\section{Kesimpulan}

Keterbukaan diri siswa sebelum diberikan layanan bimbingan kelompok memiliki kategori sedang dengan rata-rata skor sebesar 60.Keterbukaan diri siswa setelah diberikan layanan bimbingan kelompok memiliki kategori sangat tinggi dengan rata-rata skor sebesar 90.Ada peningkatan keterbukaan diri siswa secara signifikan melalui layanan bimbingan kelompok pada siswa kelas X SMA Negeri 4 Kota Lubuklinggau.

Meningkatkan keterbukaan diri siswa perlu dilakukan penelitian lanjutan mengenai keterbukaan diri yang ditinjau dengan menggunakan layanan konseling kelompok, serta dari faktor lain seperti kepribadian dan lingkungan sosialnya.

\section{Daftar Pustaka}

Asmani, J. M. (2010). Panduan Efektif Bimbingan dan Konseling di Sekolah. Jogjakarta: Diva Press

Hanifa, S. N. (2013). Meningkatkan Keterbukaan Diri dalam Komunikasi Antar Teman Sebaya Melalui Bimbingan Kelompok Teknik Johari Window pada Siswa Kelas XI IS 1 SMA Walisongo Pecangaan Jepara Tahun Ajaran 2011/2012.https://journal.unnes.ac.id/sju/index.php/jbk/, diunduh 18 Juli 2018. 
$\begin{array}{lllll}\text { Undang-UndangRepublik } & \text { Indonesia } & \text { No } & 20 & \text { Tahun }\end{array}$ TentangSistemPendidikanNaional.http://kelembagaan.ristekdikti.go.id/wpcontent/uploads/2016/08/UU_no_20_th_2003.pdf, diunduh 6 Juli 2018

Mulyati, T.; Wardhani, E. K.\& Imran, I. (2000).Modul 7Pengembangan Diri. PKBI

Prayitno. (1995). Layanan Bimbingan dan Konseling Kelompok (Dasar dan Profil). Jakarta: Ghalia Indonesia

. (2004). Seri Kegiatan Pendukung Konseling: L.1 - L.9. Padang: Universitas Negeri Padang

Setianingsih, E. S.; Sutoyo, A.\& Purwanto, E. (2014).Pengembangan Model Bimbingan Kelompok Teknik Pemecahan Masalah untuk Meningkatkan Keterbukaan Diri Siswa, dari http://journal.unnes.ac.id/artikel.sju/jubk/4610, diunduh 20 Januari 2018.

Sukardi, D. K. (2008). Pengantar Pelaksanaan Program Bimbingan dan Konseling di Sekolah. Jakarta: Rineka Cipta

Sugiyono. (2012). Metode Penelitian Pendidikan (Pendekatan Kuantitatif, Kualitatif, dan $R \& D)$. Bandung : Alfabeta

Syahrizal, D.; Sugiarto, A. (2013). Undang-Undang Sistem Pendidikan Nasional \& Aplikasinya. Jakarta: Laskar Aksara

Zuriah, N. (2009). Metodologi Penelitian Sosial dan Pendidikan (Teori - Aplikasi). Jakarta: Bumi Aksara 